\title{
Long-Term Safety and Effectiveness of the Xanthine Oxidoreductase Inhibitor, Topiroxostat in Japanese Hyperuricemic Patients with or Without Gout: A 54-week Open-label, Multicenter, Post-marketing Observational Study
}

\author{
Tomohiko Ishikawa ${ }^{1}(1) \cdot$ Tatsushi Maeda $^{2} \cdot$ Teruo Hashimoto $^{3} \cdot$ Tetsuya Nakagawa $^{2} \cdot$ Kazuhito Ichikawa $^{2}$. \\ Yasushi Sato ${ }^{4}$. Yoshihiko Kanno ${ }^{5}$
}

Published online: 3 July 2020

(c) The Author(s) 2020

\begin{abstract}
Background and Objectives Topiroxostat, a selective xanthine oxidoreductase inhibitor, is used for the management of hyperuricemic patients with or without gout in Japan. Accumulating evidence has demonstrated the efficacy of topiroxostat for the treatment of hyperuricemia with or without gout. However, the safety and efficacy of topiroxostat in the clinical setting remain unclear, and there is little large-scale clinical evidence. We conducted a post-marketing observational study over 54 weeks. Patients and Methods Patients were centrally enrolled, and case report forms of 4491 patients were collected between April 2014 and March 2019 from 825 medical sites.

Results Overall, 4329 patients were assessed for safety and 4253 patients for effectiveness. The overall incidence of adverse drug reactions was $6.95 \%$, and the incidence rates of adverse drug reactions of gouty arthritis, hepatic dysfunction, and skin disorders, which are of special interest in this study, were $0.79 \%, 1.73 \%$, and $0.95 \%$, respectively. No case of serious gouty arthritis was observed. Serum urate levels decreased stably over time and showed a significant reduction rate at 54 weeks $(21.19 \% \pm 22.07 \%)$ and on the final visit $(19.91 \% \pm 23.35 \%)$ compared to the baseline. The rates for subjects who achieved serum uric acid levels $\leq 6.0 \mathrm{mg} / \mathrm{dL}$ at 18 and 54 weeks after administration were $43.80 \%$ and $48.28 \%$, respectively.

Conclusions This study suggests that there is no particular concern about adverse drug reactions or the efficacy of topiroxostat for hyperuricemic patients with or without gout in a post-marketing setting in Japan.
\end{abstract}

Electronic supplementary material The online version of this article (https://doi.org/10.1007/s40261-020-00941-3) contains supplementary material, which is available to authorized users.

Tomohiko Ishikawa

L2-80947@fujiyakuhin.co.jp

1 Medical Affairs Department, Fuji Yakuhin Co., Ltd., 9F Kanda Square Building, 2-2-1 Kandanishiki-cho, Chiyoda-ku, Tokyo 101-8189, Japan

2 Pharmacovigilance Department, Sanwa Kagaku Kenkyusho Co., Ltd., Aichi, Japan

3 Pharmacovigilance Department, Reliability and Quality Assurance Division, Fuji Yakuhin Co., Ltd., Saitama, Japan

4 Reliability and Quality Assurance Division, Fuji Yakuhin Co., Ltd., Saitama, Japan

5 Department of Nephrology, Tokyo Medical University, Shinjuku, Tokyo, Japan

\section{Key Points}

The safety and efficacy of the novel non-purine selective xanthine oxidoreductase inhibitor, topiroxostat, were investigated over 54 weeks in a post-marketing study.

There were no new findings that would raise questions about the safety of topiroxostat under actual conditions of use, and its efficacy was shown to be the same as clinical studies had reported at the time of approval.

Topiroxostat is considered a safe and effective drug for gout and hyperuricemia in daily practice. 


\section{Introduction}

Hyperuricemia (defined as a serum urate level $>7.0 \mathrm{mg} / \mathrm{dL}$ in Japan) is a causative factor for urate deposition diseases such as urolithiasis and gouty arthritis [1]. Defects in single and multiple genes have been suggested as the cause of hyperuricemia. These reportedly affect nucleic acid metabolism-related enzymes that promote uric acid production or urate transporters that reduce renal excretion of uric acid $[2,3]$. Hyperuricemia is broadly divided into the overproduction of uric acid, the underexcretion of it, and mixed types. Recently, the existence of a renal load type, including reduced extrarenal excretion of uric acid and the overproduction of uric acid and reduced extrarenal excretion, has also been proposed [2]. Three urate transporters, URAT1/SLC22A12, GLUT9/SLC2A9, and ABCG2/ $\mathrm{BCRP}$, are reported to play crucial roles in the regulation of serum urate level, and their dysfunction causes urate transport disorders (hypouricemia and/or hyperuricemia). ABCG2 variants have been shown to have stronger effects on the risk of hyperuricemia/gout than major environmental risk factors such as obesity and heavy drinking [4].

Reducing serum urate levels and maintaining it at or below $6.0 \mathrm{mg} / \mathrm{dL}$ is a major target in treating hyperuricemia to prevent gouty arthritis [5-8]. Drugs that reduce serum uric acid levels are roughly classified into two types: uric acid synthesis inhibitors that inhibit xanthine oxidoreductase (XOR) and uric acid excretion accelerators that inhibit renal uric acid reabsorption. Topiroxostat, (Topirolic ${ }^{\circledR}$ tablets and Uriadec ${ }^{\circledR}$ tablets) a non-purine selective XOR inhibitor, belongs to the group of uric acid synthesis inhibitors. It is a hybrid inhibitor that inhibits enzyme activity by covalent binding with molybdenum and by interaction with amino acid residues in the substrate-binding pocket $[9,10]$.

There have been several reports on the safety and efficacy of topiroxostat, mainly in development trials, and topiroxostat not only reduces serum uric acid levels [11-13] but also may have a possible positive effect on renal function [14-17].

We report here the results of a post-marketing study conducted to collect information on the safety, efficacy, and proper use of topiroxostat.

\section{Patients and Methods}

\subsection{Study Design}

This was a prospective, observational, multicenter postmarketing study carried out in routine clinical practice, and co-sponsored by the manufacturers to investigate the safety and effectiveness of topiroxostat (Topiloric ${ }^{\circledR}$, Fuji Yakuhin Co., Ltd., Saitama, Japan) and Uriadec ${ }^{\circledR}$ (Sanwa Kagaku Kenkyusho Co., Ltd., Aichi, Japan). The study was carried out in accordance with the Good Post-Marketing Study Practice standards specified by the Ministry of Health, Labor and Welfare in Japan.

\subsection{Participants and Data Assessment}

Patients were recruited from medical institutions throughout Japan and were enrolled using a central registration system from April 2014 to 31 March 2017. Each patient was followed up for 54 weeks from the date of first topiroxostat administration, using Electronic Data Capture.

This study collected patient background information, such as age, gender, BMI, reasons for using this drug, disease duration of gout or hyperuricemia, and concomitant disease.

Safety was assessed according to the incidence of adverse drug reactions (ADRs), the change in clinical laboratory tests of aspartate transaminase (AST), alanine aminotransferase (ALT), alkaline phosphatase (ALP), gamma-glutamyl transpeptidase $(\gamma$-GTP), total bilirubin, and triglycerides, as well as total cholesterol, high-density lipoprotein (HDL) cholesterol, low-density lipoprotein (LDL) cholesterol, blood urea nitrogen (BUN), serum creatinine $(\mathrm{Cr})$, and hemoglobin A1c (HbA1c). Urinalysis (protein and occult blood) was performed, and blood pressure, pulse, body weight, estimated glomerular filtration rate (eGFR) and urinary albumin/Cr ratio were documented. Furthermore, the incidence of cardiovascular adverse events and ADRs from renal and urinary tract disorders were also tabulated.

Efficacy endpoints were changes in serum uric acid levels, a decrease rate of serum uric acid levels at 18 weeks and 54 weeks after administration and at the final evaluation, and the achievement rate of $\leq 6 \mathrm{mg} / \mathrm{dL}$.

Priority research factors include gouty arthritis, hepatic dysfunction, skin disorders, and safety and efficacy in special patient subgroups. These included the elderly, females, and patients with hepatic or renal dysfunction.

\subsection{Statistical Analysis}

The subgroup analysis of the incidence of ADRs by patient background factors and the special patient subgroups were tested using the Chi square test or Fisher's exact test, and the analysis of changes in clinical test values was performed using the one-sample $t$ test. A level of less than 5\% (twosided) was considered significant. Adverse events (AEs) and ADRs were categorized according to the Medical Dictionary for Regulatory Activities/Japanese edition (MedDRA/J) version 22.0. Changes in serum uric acid levels and decrease 
rates were analyzed using one-sample $t$ tests, and subgroup analysis of serum uric acid decrease rates in specific patient populations was performed by analysis of variance.

\subsection{Trial Registration}

This PMS study was retrospectively registered on JapicClinical Trials Information as JapicCTI-173783 on November 22, 2017.

\section{Results}

\subsection{Patient Disposition and Characteristics}

Figure 1 shows the patient disposition in the study. In total, 4642 patients were registered at 825 medical sites across Japan. With the exception of 151 cases for which the case report form (CRF) could not be collected, 4491 CRFs (18 weeks) and 3657 CRFs (54 weeks) were collected and fixed.

Of the 4491 cases, 162 were excluded owing to the absence of visits after enrollment $(n=158)$, duplicate registration $(n=3)$, and lack of exposure to the drug $(n=1)$, leaving 4329 patients for the safety analyses. An additional 76 patients were excluded from the effectiveness analyses, (73-no effectiveness data available, 2-prior use of topiroxostat, 1 off-label use), leaving 4253 patients.

Table 1 summarizes the baseline characteristics of the 4329 safety analysis subjects in this study. The mean serum uric acid level was $8.11 \pm 1.46 \mathrm{mg} / \mathrm{dL}$, and the number of cases with a serum uric acid level of $7.0 \mathrm{mg} / \mathrm{dL}$ or more was $3436(79.37 \%)$.

The details of specific patient populations (elderly, female, hepatic dysfunction, renal dysfunction) were as follows: there were 2364 (54.61\%) elderly people aged $\geq 65$, and $1238(28.60 \%)$ aged $>75$. There were 851 (19.66\%) female patients, 434 (10.03\%) hepatic dysfunction patients, 3469 (80.13\%) patients with renal dysfunction.

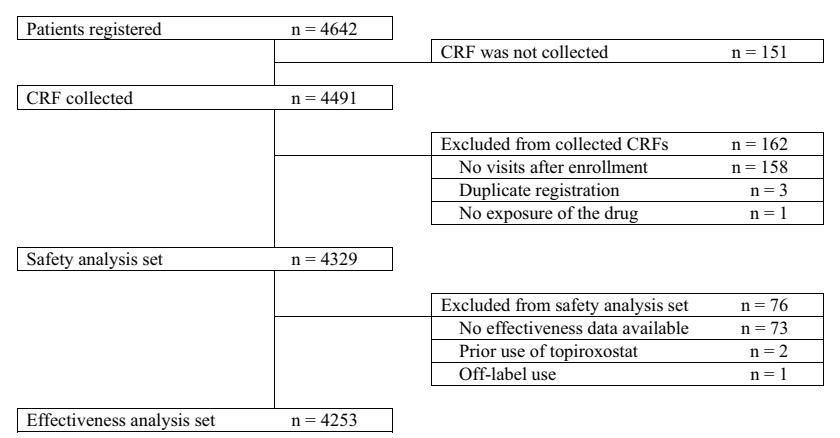

Fig. 1 Patient disposition. $C R F$ case report form

\subsection{Usage Status of this Drug}

The average daily dose of the 4329 patients subject to safety analysis was $50.57 \mathrm{mg} /$ day. The dose escalation was 794 cases (18.34\%), and the one-step dose escalation was the highest in 638 cases (14.74\%).

Of the 4329 safety analysis subjects in this study, 3203 (73.99\%) completed use for one year (54 weeks), and 1126 (26.01\%) discontinued or dropped out. The main reasons for discontinuation or withdrawal included no visit [365 cases (8.43\%)], AEs [198 cases (4.57\%)], the achievement of the treatment purpose [115 cases $(2.66 \%)$ ], change of hospital [104 cases (2.40\%)], or failure to collect the CRF by the end of the survey due to the lack of the cooperation of a doctor [199 cases $(4.60 \%)]$.

\subsection{Safety Results}

ADRs reported by attending physicians are summarized in Table 2. All observed ADRs are listed in the Table S2. In 4329 cases subject to safety analysis, 390 ADRs occurred in 301 cases, and the overall incidence of ADRs was 6.95\%, which was lower than the $35.35 \%$ (292/826) incidence of ADRs in clinical trials up to the time of approval.

The main ADRs were abnormal hepatic function $(n=39$, $0.90 \%)$, gouty arthritis $(n=34,0.79 \%)$, pruritus and renal impairment $(n=15,0.35 \%$ each $)$, and liver disorders $(n=12$, $0.28 \%$ ).

Table 3 shows the incidence of ADRs by patient background factors. Background factors with a high incidence of ADRs included history of gouty arthritis, gout nodules, and concomitant disease (renal disease, cardiovascular disease, hypertension), with a significant difference compared to the absence of each. In addition, there was a significant difference in the incidence of ADRs in the presence or absence of gradual increased dosing, the total number of days of administration, and the total dose.

\subsubsection{Changes in Clinical Test Values}

Serum creatinine tended to increase after 10 weeks' administration, and a significant difference was observed compared to the start of administration after 30 weeks' administration, but the mean change after 54 weeks was a slight increase of 0.066 , BUN did not show an increasing trend. The renal dysfunction patients (eGFR $<90 \mathrm{~mL} / \mathrm{min} / 1.73 \mathrm{~m}^{2}: 80.13 \%$ ) and the elderly (aged $\geq 65$ years, $54.61 \%$ ) were more likely to be affected by the natural history of these patients. Although there were also significant differences in ALT, ALP, $\gamma$-GTP, total bilirubin, triglycerides (TG), total cholesterol, HDL cholesterol, LDL cholesterol, BUN, eGFR, HbA1c, blood pressure (systolic, diastolic) and body weight, the fluctuation range was small or it was not a change for the worse. 
Table 1 Patient baseline characteristics of safety analysis subjects $(N=4329)$

\begin{tabular}{|c|c|}
\hline Characteristics & Value \\
\hline Age (years) & $64.1 \pm 15.2 ; 66.0(13-103)$ \\
\hline$<65$ & $1965(45.39)$ \\
\hline 65 to $<75$ & $1126(26.01)$ \\
\hline$\geq 75$ & $1238(28.60)$ \\
\hline \multicolumn{2}{|l|}{ Gender } \\
\hline Male & $3478(80.34)$ \\
\hline Female & $851(19.66)$ \\
\hline $\operatorname{BMI}\left(\mathrm{kg} / \mathrm{m}^{2}\right)[n=3250]$ & $25.12 \pm 4.36 ; 24.60(12.9-64.2)$ \\
\hline$<18.5$ & $119(2.75)$ \\
\hline 18.5 to $<25$ & $1613(37.26)$ \\
\hline 25 to $<30$ & $1151(26.59)$ \\
\hline 30 to $<35$ & $279(6.44)$ \\
\hline 35 to $<40$ & $70(1.62)$ \\
\hline$\geq 40$ & $18(0.42)$ \\
\hline Unknown & $1079(24.92)$ \\
\hline \multicolumn{2}{|l|}{ Reason (including double counts) } \\
\hline Gout & $728(16.82)$ \\
\hline Hyperuricemia & $3974(91.80)$ \\
\hline Others & $8(0.18)$ \\
\hline \multicolumn{2}{|c|}{ Disease duration of gout or hyperuricemia (years) } \\
\hline$<5$ & $2005(46.32)$ \\
\hline 5 to $<10$ & $527(12.17)$ \\
\hline$\geq 10$ & $348(8.04)$ \\
\hline Unknown & $1449(33.47)$ \\
\hline History of gouty arthritis & $663(15.32)$ \\
\hline Gout nodules & $86(1.99)$ \\
\hline \multicolumn{2}{|l|}{ Disease classification $^{\mathrm{a}}$} \\
\hline Overproduction & $427(9.86)$ \\
\hline Underexcretion & $365(8.43)$ \\
\hline Mixed & $279(6.44)$ \\
\hline Normal & $34(0.79)$ \\
\hline Not evaluated & $3224(74.47)$ \\
\hline Concomitant disease & $3819(88.22)$ \\
\hline Liver disease & $1319(30.47)$ \\
\hline Renal disease & $1868(43.15)$ \\
\hline Hemodialysis & $91(2.10)$ \\
\hline Cardiovascular disease & $846(19.54)$ \\
\hline Hypertension & $2720(62.83)$ \\
\hline Hyperlipidemia (dyslipidemia) & $2213(51.12)$ \\
\hline Diabetes & $1112(25.69)$ \\
\hline Others & $1339(30.93)$ \\
\hline Usual alcohol drinker & $1866(43.10)$ \\
\hline Serum uric acid at start $(\mathrm{mg} / \mathrm{dL})[N=4014]$ & $8.11 \pm 1.46 ; 8.10(1.4-1.3)$ \\
\hline$<6.0$ & $318(7.35)$ \\
\hline 6.0 to $<7.0$ & $260(6.01)$ \\
\hline 7.0 to $<8.0$ & $1070(24.72)$ \\
\hline 8.0 to $<9.0$ & $1440(33.26)$ \\
\hline 9.0 to $<10.0$ & 605 (13.98) \\
\hline$\geq 10.0$ & $321(7.42)$ \\
\hline Unknown & $315(7.28)$ \\
\hline
\end{tabular}


Table 1 (continued)

\begin{tabular}{ll}
\hline Characteristics & Value \\
\hline Hepatic dysfunction (baseline AST, ALT $\left.[\mathrm{U} / \mathrm{L}]^{\mathrm{b}}\right)$ Severity & $3137(72.46)$ \\
No $($ AST $<50$ and ALT $<50)$ & $360(8.32)$ \\
Mild (AST 50 to $<100$ or ALT 50 to $<100)$ & $72(1.66)$ \\
Moderate (AST 100 to $<500$ or ALT 100 to $<500)$ & $2(0.05)$ \\
Severe (AST $\geq 500$ or ALT $\geq 500)$ & $758(17.51)$ \\
Unknown & $257(5.94)$ \\
Renal dysfunction(baseline eGFR $\left.\left[\mathrm{mL} / \mathrm{min} / 1.73 \mathrm{~m}^{2}\right]^{\mathrm{b}}\right)$ Severity & $1359(31.39)$ \\
No $(\geq 90)$ & $1551(35.83)$ \\
Mild $(60$ to $<90)$ & $356(8.22)$ \\
Moderate $(30$ to $<60)$ & $203(4.69)$ \\
Severe $(15$ to $<30)$ & $603(13.93)$ \\
End stage renal failure $(<15)$ & $3467(80.09)$ \\
Unknown & $944(21.81)$ \\
Other concomitant medications & $110(2.54)$ \\
Switching from other hyperuricemia treatments & \\
Concomitant use of hyperuricemia drugs & \\
\hline
\end{tabular}

Values are expressed as $n(\%)$; mean $\pm \mathrm{SD}$; median (range)

$A L T$ alanine transaminase, $A S T$ aspartate transaminase, $B M I$ body mass index, $C R F$ case report form, $e G F R$ estimated glomerular filtration rate, $S D$ standard deviation

${ }^{a}$ For the classification of hyperuricemia, the input contents of the CRF were used as is, without specifying the measurement method

budgment based only on baseline clinical test values

\subsubsection{Key Safety Research Items}

The ADRs of gouty arthritis, hepatic dysfunction, and skin disorders were examined as research items with special interest.

In 4329 safety analysis cases, the incidence rates of ADRs of gouty arthritis, hepatic dysfunction, and skin disorders were $0.79 \%$ (34 cases), $1.73 \%$ (75 cases) and $0.95 \%$ (41 cases), respectively (Table 4$)$. No serious gouty arthritis was observed. One case each of serious hepatic dysfunction, hepatic cirrhosis, and liver disorder occurred. There was one case each of serious skin disorder, drug eruption, and urticaria. In skin disorders, in terms of the onset period, 19 cases occurred within 42 days or fewer, and 22 cases occurred on a total dose of less than $2500 \mathrm{mg}$. The incidence was high in the early stage of administration.

\subsubsection{Safety in Special Patient Populations}

The incidence of ADRs is shown in elderly patients, female patients, and patients with hepatic or renal dysfunction (Table 3). Such patients have not been sufficiently studied because of the small numbers in reported clinical trials. In the stratified analysis by age, gender, and hepatic or renal function, no significant difference was found in the incidence of ADRs in any of the subgroups.

\subsubsection{Other Analysis Items}

Cardiovascular AEs The AE rate of cardiovascular events was $0.79 \%$ (34/4329 cases) (Table 5). There were no significant changes in the relevant laboratory test values (TG, total cholesterol, HDL cholesterol, LDL cholesterol, or in blood pressure, and pulse).

ADRs of renal and urinary tract disorders The incidence of ADRs of renal and urinary tract disorders was $0.16 \%$ (7/4329 cases), of which five were presence of blood urine and one was urinary calculus and hemorrhagic cystitis (Table 5).

\subsection{Efficacy}

Changes in the serum uric acid level during the administration of topiroxostat are shown in Fig. 2, and the rate of decrease of serum uric acid levels are shown in Table 6. In 4253 patients subject to efficacy analysis, the mean value of serum uric acid at the start of administration was $8.11 \pm 1.46 \mathrm{mg} / \mathrm{dL}$ (4014 cases), the mean value after 18 weeks was $6.35 \pm 1.47 \mathrm{mg} / \mathrm{dL}$ ( 2744 cases). The mean value after 54 weeks was $6.14 \pm 1.31 \mathrm{mg} / \mathrm{dL}$ ( 2274 cases). In addition, the average value at the final evaluation, including the discontinuation of administration and the end of administration, was $6.31 \pm 1.46 \mathrm{mg} / \mathrm{dL}$ (3935 cases). 
Table 2 Incidence of adverse drug reactions observed in $\geq 3$ patients

\begin{tabular}{|c|c|}
\hline Preferred term & $n(\%)$ \\
\hline No. of patients analyzed & 4329 \\
\hline No. of patients with ADRs & 301 \\
\hline Incidence of ADRs & $6.95 \%$ \\
\hline Hepatic function abnormal & $39(0.90 \%)$ \\
\hline Gouty arthritis & $34(0.79 \%)$ \\
\hline Pruritus & $15(0.35 \%)$ \\
\hline Renal impairment & $15(0.35 \%)$ \\
\hline Liver disorder & $12(0.28 \%)$ \\
\hline Rash & $8(0.18 \%)$ \\
\hline Blood triglycerides increased & $8(0.18 \%)$ \\
\hline Hypertriglyceridemia & $7(0.16 \%)$ \\
\hline Drug eruption & $7(0.16 \%)$ \\
\hline Alanine aminotransferase increased & $7(0.16 \%)$ \\
\hline Blood creatinine increased & $7(0.16 \%)$ \\
\hline Blood urea increased & $7(0.16 \%)$ \\
\hline Diarrhea & $6(0.14 \%)$ \\
\hline Protein urine present & $6(0.14 \%)$ \\
\hline Hyperlipidemia & $5(0.12 \%)$ \\
\hline Blood pressure increased & $5(0.12 \%)$ \\
\hline Gamma-glutamyl-transferase increased & $5(0.12 \%)$ \\
\hline Blood urine present & $5(0.12 \%)$ \\
\hline Aspartate aminotransferase increased & $4(0.09 \%)$ \\
\hline Pneumonia & $3(0.07 \%)$ \\
\hline Iron deficiency anemia & $3(0.07 \%)$ \\
\hline Diabetes mellitus & $3(0.07 \%)$ \\
\hline Hypertension & $3(0.07 \%)$ \\
\hline Gastro-esophageal reflux disease & $3(0.07 \%)$ \\
\hline Nausea & $3(0.07 \%)$ \\
\hline Malaise & $3(0.07 \%)$ \\
\hline Low-density lipoprotein increased & $3(0.07 \%)$ \\
\hline Blood alkaline phosphatase increased & $3(0.07 \%)$ \\
\hline
\end{tabular}

$A D R$ adverse drug reaction

MedDRA/J version (22.0)

The decrease rate of serum uric acid level was $19.03 \% \pm 23.90 \%$ (2639 cases) after 18 weeks, $21.19 \% \pm 22.07 \%$ (2191 cases) after 54 weeks, and $19.91 \% \pm 23.35 \%$ (3706 cases) at the time of final evaluation, all showed a significant decrease compared to the start of administration.

The achievement rate of serum uric acid level of $6.0 \mathrm{mg} /$ dL or less was $43.80 \%$ (1202/2744 cases) after 18 weeks, $48.28 \%$ (1098/2274 cases) after 54 weeks, and $44.55 \%$ $(1753 / 3935$ cases) at the final evaluation (Table 7). In addition, the achievement rate of $6.0 \mathrm{mg} / \mathrm{dL}$ or less in patients whose serum uric acid level exceeded $6.0 \mathrm{mg} / \mathrm{dL}$ at the start of administration was $41.87 \%$ (1004/2398 cases) after 18 weeks, and $46.05 \%$ (914/1985 cases) after 54 weeks, and $42.39 \%(1434 / 3383$ cases $)$ at the time of final evaluation (Table 7).
We examined the rate of decrease in serum uric acid levels in elderly patients, female patients, and hepatic or renal dysfunction patients. The same decrease was observed as in non-elderly patients, and patients without hepatic or renal dysfunction. Gender stratification analysis, however, showed that females had significantly higher reduction rates than males (Table 8).

\section{Discussion}

The safety and efficacy of topiroxostat under daily use were confirmed by this 54-week post-marketing study. In general, randomized controlled trials can provide the highest levels of clinical evidence with the least bias but cannot collect all data relevant to use in routine clinical practice. Therefore, 
Table 3 Incidence of adverse drug reactions by patients' background factors

\begin{tabular}{|c|c|c|c|c|c|c|}
\hline \multirow{2}{*}{$\begin{array}{l}\text { Patient characteristics } \\
\text { Total }\end{array}$} & \multirow[t]{2}{*}{ Category } & \multirow{2}{*}{$\begin{array}{l}\text { No. of patients } \\
4329\end{array}$} & \multicolumn{2}{|c|}{$\begin{array}{l}\text { No. of } \\
\text { patients with } \\
\text { ADRs }(\%)\end{array}$} & \multirow{2}{*}{$\begin{array}{l}\text { No of ADRs } \\
390\end{array}$} & \multirow{2}{*}{$\begin{array}{l}\text { Statistics } \\
-\end{array}$} \\
\hline & & & 301 & $(6.95)$ & & \\
\hline \multirow[t]{3}{*}{ Age (years) } & $<65$ & 1965 & 131 & $(6.67)$ & 177 & \multirow[t]{3}{*}{${ }^{c} p=0.1216$} \\
\hline & 65 to $<75$ & 1126 & 69 & $(6.13)$ & 88 & \\
\hline & $\geq 75$ & 1238 & 101 & $(8.16)$ & 125 & \\
\hline \multirow[t]{2}{*}{ Gender } & Male & 3478 & 233 & $(6.70)$ & 300 & \multirow[t]{2}{*}{${ }^{\mathrm{f}} p=0.2009$} \\
\hline & Female & 851 & 68 & (7.99) & 90 & \\
\hline \multirow[t]{7}{*}{ BMI $\left[\mathrm{kg} / \mathrm{m}^{2}\right]$} & $<18.5$ & 119 & 13 & (10.92) & 16 & \multirow[t]{7}{*}{${ }^{\mathrm{c}} p=0.2294$} \\
\hline & 18.5 to $<25$ & 1613 & 142 & $(8.80)$ & 186 & \\
\hline & 25 to $<30$ & 1151 & 79 & $(6.86)$ & 99 & \\
\hline & 30 to $<35$ & 279 & 22 & $(7.89)$ & 33 & \\
\hline & 35 to $<40$ & 70 & 4 & $(5.71)$ & 5 & \\
\hline & $\geq 40$ & 18 & 0 & $(0.00)$ & 0 & \\
\hline & Unknown & 1079 & 41 & $(3.80)$ & 51 & \\
\hline \multirow[t]{3}{*}{ Reason (including double counts) } & Gout & 728 & 59 & $(8.10)$ & 79 & \multirow[t]{3}{*}{-} \\
\hline & Hyperuricemia & 3974 & 277 & $(6.97)$ & 356 & \\
\hline & Others & 8 & 0 & $(0.00)$ & 0 & \\
\hline \multirow{4}{*}{$\begin{array}{l}\text { Disease duration of gout or hyperurice- } \\
\text { mia (years) }\end{array}$} & $<5$ & 2005 & 127 & $(6.33)$ & 159 & \multirow[t]{4}{*}{${ }^{\mathrm{c}} p=0.3993$} \\
\hline & 5 to $<10$ & 527 & 39 & $(7.40)$ & 54 & \\
\hline & $\geq 10$ & 348 & 28 & $(8.05)$ & 33 & \\
\hline & Unknown & 1449 & 107 & $(7.38)$ & 144 & \\
\hline \multirow[t]{2}{*}{ History of gouty arthritis } & No & 3666 & 235 & $(6.41)$ & 298 & \multirow[t]{2}{*}{${ }^{\mathrm{f}} p=0.0016$} \\
\hline & Yes & 663 & 66 & $(9.95)$ & 92 & \\
\hline \multirow[t]{2}{*}{ Gout nodules } & No & 4243 & 289 & $(6.81)$ & 370 & \multirow[t]{2}{*}{${ }^{\mathrm{f}} p=0.0168$} \\
\hline & Yes & 86 & 12 & $(13.95)$ & 20 & \\
\hline \multirow[t]{5}{*}{ Disease classification $^{a}$} & Overproduction type & 427 & 22 & $(5.15)$ & 25 & \multirow[t]{5}{*}{${ }^{\mathrm{c}} p=0.4502$} \\
\hline & Underexcretion type & 365 & 23 & $(6.30)$ & 31 & \\
\hline & Mixed & 279 & 17 & $(6.09)$ & 24 & \\
\hline & Normal & 34 & 0 & $(0.00)$ & 0 & \\
\hline & Not evaluated & 3224 & 239 & $(7.41)$ & 310 & \\
\hline Concomitant disease & No & 510 & 15 & $(2.94)$ & 16 & ${ }^{\mathrm{f}} p<0.0001$ \\
\hline & Yes & 3819 & 286 & $(7.49)$ & 374 & \\
\hline Liver disease & No & 3010 & 199 & $(6.61)$ & 252 & ${ }^{\mathrm{f}} p=0.1941$ \\
\hline & Yes & 1319 & 102 & $(7.73)$ & 138 & \\
\hline Renal disease & No & 2461 & 135 & $(5.49)$ & 175 & ${ }^{\mathrm{f}} p<0.0001$ \\
\hline & Yes & 1868 & 166 & $(8.89)$ & 215 & \\
\hline Hemodialysis & No & 4238 & 297 & $(7.01)$ & 385 & ${ }^{\mathrm{f}} p=0.4099$ \\
\hline & Yes & 91 & 4 & $(4.40)$ & 5 & \\
\hline Cardiovascular disease & No & 3483 & 219 & $(6.29)$ & 280 & ${ }^{\mathrm{f}} p=0.0009$ \\
\hline & Yes & 846 & 82 & $(9.69)$ & 110 & \\
\hline Hypertension & No & 1609 & 91 & $(5.66)$ & 115 & ${ }^{\mathrm{f}} p=0.0094$ \\
\hline & Yes & 2720 & 210 & $(7.72)$ & 275 & \\
\hline Hyperlipidemia (dyslipidemia) & No & 2116 & 137 & $(6.47)$ & 168 & ${ }^{\mathrm{f}} p=0.2324$ \\
\hline & Yes & 2213 & 164 & $(7.41)$ & 222 & \\
\hline Diabetes & No & 3217 & 229 & $(7.12)$ & 299 & ${ }^{\mathrm{f}} p=0.4945$ \\
\hline & Yes & 1112 & 72 & $(6.47)$ & 91 & \\
\hline Others & No & 2990 & 163 & $(5.45)$ & 200 & ${ }^{\mathrm{f}} p<0.0001$ \\
\hline & Yes & 1339 & 138 & $(10.31)$ & 190 & \\
\hline
\end{tabular}


Table 3 (continued)

\begin{tabular}{|c|c|c|c|c|c|c|}
\hline \multirow{2}{*}{$\begin{array}{l}\text { Patient characteristics } \\
\text { Usual alcohol drinker }\end{array}$} & \multirow{2}{*}{$\begin{array}{l}\text { Category } \\
\text { No }\end{array}$} & \multirow{2}{*}{$\begin{array}{l}\text { No. of patients } \\
1828\end{array}$} & \multicolumn{2}{|c|}{$\begin{array}{l}\text { No. of } \\
\text { patients with } \\
\text { ADRs (\%) }\end{array}$} & \multirow{2}{*}{$\begin{array}{l}\text { No of ADRs } \\
146\end{array}$} & \multirow{2}{*}{$\begin{array}{l}\text { Statistics } \\
{ }^{\mathrm{f}} p=0.7916\end{array}$} \\
\hline & & & 119 & $(6.51)$ & & \\
\hline & Yes & 1866 & 126 & $(6.75)$ & 176 & \\
\hline & Unknown & 635 & 56 & $(8.82)$ & 68 & \\
\hline \multirow[t]{7}{*}{ Serum uric acid at baseline $[\mathrm{mg} / \mathrm{dL}]$} & $<6.0$ & 318 & 21 & $(6.60)$ & 28 & ${ }^{\mathrm{c}} p=0.7160$ \\
\hline & 6.0 to $<7.0$ & 260 & 18 & $(6.92)$ & 29 & \\
\hline & 7.0 to $<8.0$ & 1070 & 72 & $(6.73)$ & 102 & \\
\hline & 8.0 to $<9.0$ & 1440 & 101 & $(7.01)$ & 124 & \\
\hline & 9.0 to $<10.0$ & 605 & 45 & $(7.44)$ & 52 & \\
\hline & $\geq 10.0$ & 321 & 30 & $(9.35)$ & 39 & \\
\hline & Unknown & 315 & 14 & $(4.44)$ & 16 & \\
\hline \multirow{5}{*}{$\begin{array}{l}\text { Hepatic dysfunction (baseline AST, ALT } \\
{[\text { U/L] })^{\mathrm{b}} \text { Severity }}\end{array}$} & No $($ AST $<50$ and ALT $<50)$ & 3137 & 238 & $(7.59)$ & 315 & ${ }^{\mathrm{c}} p=0.4665$ \\
\hline & $\begin{array}{l}\text { Mild (AST } 50 \text { to }<100 \text { or ALT } 50 \\
\text { to }<100 \text { ) }\end{array}$ & 360 & 28 & $(7.78)$ & 35 & \\
\hline & $\begin{array}{l}\text { Moderate (AST } 100 \text { to }<500 \text { or ALT } 100 \\
\text { to }<500 \text { ) }\end{array}$ & 72 & 2 & $(2.78)$ & 2 & \\
\hline & Severe $(\mathrm{AST} \geq 500$ or $\mathrm{ALT} \geq 500)$ & 2 & 0 & $(0.00)$ & 0 & \\
\hline & Unknown & 758 & 33 & $(4.35)$ & 38 & \\
\hline \multirow{6}{*}{$\begin{array}{l}\text { Renal dysfunction (baseline eGFR [mL/ } \\
\left.\left.\min / 1.73 \mathrm{~m}^{2}\right]\right)^{\mathrm{b}} \text { Severity }\end{array}$} & No $(\geq 90)$ & 257 & 19 & $(7.39)$ & 24 & ${ }^{\mathrm{c}} p=0.1127$ \\
\hline & Mild $(60$ to $<90)$ & 1359 & 83 & $(6.11)$ & 105 & \\
\hline & Moderate $(30$ to $<60)$ & 1551 & 133 & $(8.58)$ & 181 & \\
\hline & Severe $(15$ to $<30)$ & 356 & 29 & $(8.15)$ & 31 & \\
\hline & End stage renal failure $(<15)$ & 203 & 19 & $(9.36)$ & 29 & \\
\hline & Unknown & 603 & 18 & $(2.99)$ & 20 & \\
\hline Gradual increase & No & 3535 & 220 & $(6.22)$ & 283 & ${ }^{\mathrm{f}} p=0.0001$ \\
\hline \multirow[t]{5}{*}{ Incremental phase } & Yes & 794 & 81 & $(10.20)$ & 107 & \\
\hline & No & 3535 & 220 & $(6.22)$ & 283 & ${ }^{\mathrm{c}} p<0.0001$ \\
\hline & Once & 638 & 58 & $(9.09)$ & 74 & \\
\hline & Twice & 139 & 20 & (14.39) & 29 & \\
\hline & 3 times & 17 & 3 & $(17.65)$ & 4 & \\
\hline \multirow[t]{7}{*}{ Average single dose [mg/time] } & $<10$ & 0 & 0 & - & 0 & ${ }^{c} p=0.7660$ \\
\hline & 10 to $<20$ & 16 & 1 & $(6.25)$ & 1 & \\
\hline & 20 to $<40$ & 3157 & 210 & $(6.65)$ & 270 & \\
\hline & 40 to $<60$ & 1004 & 79 & $(7.87)$ & 107 & \\
\hline & 60 to $<80$ & 120 & 9 & $(7.50)$ & 10 & \\
\hline & 80 to $<120$ & 32 & 2 & $(6.25)$ & 2 & \\
\hline & $\geq 120$ & 0 & 0 & - & 0 & \\
\hline \multirow[t]{9}{*}{ Average daily dose [mg/day] } & $<10$ & 0 & 0 & - & 0 & ${ }^{\mathrm{c}} p=0.4172$ \\
\hline & 10 to $<20$ & 8 & 0 & $(0.00)$ & 0 & \\
\hline & 20 to $<40$ & 638 & 39 & $(6.11)$ & 49 & \\
\hline & 40 to $<60$ & 2468 & 161 & $(6.52)$ & 200 & \\
\hline & 60 to $<80$ & 412 & 32 & $(7.77)$ & 46 & \\
\hline & 80 to $<120$ & 682 & 59 & $(8.65)$ & 84 & \\
\hline & 120 to $<160$ & 89 & 8 & (8.99) & 9 & \\
\hline & 160 to $<240$ & 32 & 2 & $(6.25)$ & 2 & \\
\hline & $\geq 240$ & 0 & 0 & - & 0 & \\
\hline
\end{tabular}


Table 3 (continued)

\begin{tabular}{|c|c|c|c|c|c|c|}
\hline Patient characteristics & Category & No. of patients & $\begin{array}{l}\text { No. } \\
\text { patie } \\
\text { ADR }\end{array}$ & $\begin{array}{l}\text { f } \\
\text { nts with } \\
\text { s (\%) }\end{array}$ & No of ADRs & Statistics \\
\hline \multirow[t]{8}{*}{ Total administration days [day] } & $<14$ & 27 & 11 & $(40.74)$ & 14 & \multirow[t]{8}{*}{${ }^{\mathrm{c}} p<0.0001$} \\
\hline & 14 to $<42$ & 153 & 31 & $(20.26)$ & 39 & \\
\hline & 42 to $<70$ & 113 & 20 & $(17.70)$ & 21 & \\
\hline & 70 to $<126$ & 197 & 20 & $(10.15)$ & 25 & \\
\hline & 126 to $<210$ & 398 & 29 & $(7.29)$ & 32 & \\
\hline & 210 to $<294$ & 133 & 23 & (17.29) & 27 & \\
\hline & 294 to $<378$ & 120 & 13 & $(10.83)$ & 15 & \\
\hline & $\geq 378$ & 3188 & 154 & $(4.83)$ & 217 & \\
\hline \multirow[t]{7}{*}{ Total dose $[\mathrm{mg}]$} & $<2500$ & 254 & 55 & $(21.65)$ & 67 & \multirow[t]{7}{*}{${ }^{\mathrm{c}} p<0.0001$} \\
\hline & 2500 to $<5000$ & 276 & 23 & $(8.33)$ & 24 & \\
\hline & 5000 to $<10,000$ & 728 & 48 & $(6.59)$ & 62 & \\
\hline & 10,000 to $<20,000$ & 2030 & 102 & $(5.02)$ & 129 & \\
\hline & 20,000 to $<30,000$ & 423 & 31 & $(7.33)$ & 45 & \\
\hline & 30,000 to $<40,000$ & 458 & 25 & $(5.46)$ & 43 & \\
\hline & $\geq 40,000$ & 160 & 17 & $(10.63)$ & 20 & \\
\hline \multirow[t]{2}{*}{ Other concomitant medications } & No & 862 & 23 & $(2.67)$ & 30 & \multirow[t]{2}{*}{${ }^{\mathrm{f}} p<0.0001$} \\
\hline & Yes & 3467 & 278 & $(8.02)$ & 360 & \\
\hline \multirow{2}{*}{$\begin{array}{l}\text { Switching from other hyperuricemia } \\
\text { treatments }\end{array}$} & No & 3385 & 218 & $(6.44)$ & 285 & \multirow[t]{2}{*}{${ }^{\mathrm{f}} p=0.0138$} \\
\hline & Yes & 944 & 83 & $(8.79)$ & 105 & \\
\hline \multirow{2}{*}{$\begin{array}{l}\text { Concomitant medications for hyperurice- } \\
\text { mia treatment }\end{array}$} & No & 4219 & 291 & $(6.90)$ & 373 & \multirow[t]{2}{*}{${ }^{\mathrm{f}} p=0.3425$} \\
\hline & Yes & 110 & 10 & $(9.09)$ & 17 & \\
\hline
\end{tabular}

$A D R$ adverse drug reaction, $A L T$ alanine transaminase, $A S T$ aspartate transaminase, $C R F$ case report form, $e G F R$ estimated glomerular filtration rate, $C_{p}$ Chi square test, $F_{p}$ Fisher's exact test

${ }^{a}$ For the classification of hyperuricemia, the input contents of the CRF were used as is, without specifying the measurement method

bJudgment based only on baseline clinical test values

the present study is important because it provides feedback on the use of topiroxostat in routine clinical practice.

As for the safety profile, the incidence of ADRs with topiroxostat was $6.95 \%$ in this study, indicating a lower rate compared with the aggregated results $(35.35 \%)$ in the preapproval trials. As priority items related to safety, we investigated the incidence of ADRs of gouty arthritis, hepatic dysfunction and skin disorders, and safety in the elderly, and in patients with hepatic or renal dysfunction, and in female patients. No problematic events were observed in the subgroups.

The prevalence of gout is estimated to be over $1 \%$ in men aged $>30$ years and is still on the rise [18]. In addition, the occurrence of side effects of gouty arthritis associated with the treatment of hyperuricemia has become a problem. In this study, the incidence of gouty arthritis was $0.79 \%$ (34 of 4329 patients), with no serious cases, and was lower than that seen at the time of approval of $10.05 \%$ (83/826 patients). These results suggest that topiroxostat is a useful drug for patients with gout and hyperuricemia with a low incidence of gouty arthritis even when lowering serum uric acid levels.

It has been suggested that since topiroxostat is not affected by mild-to-moderate renal dysfunction, adjustment of dosage and administration is not required for these patients [14], and this study confirmed that there was no significant difference in the incidence of ADRs according to the severity of eGFR at the baseline.

As a result of examining the incidence of ADRs by patient background factors, when the total number of administration days was less than 14 and the total dose was less than $2500 \mathrm{mg}$, the incidence of ADRs was high; however, the effect of patients who discontinued the drug due to the appearance of side effects in the early stage of administration was considered.

Although there was a significant difference in the incidence rate of ADRs by some patient background factors, the tendency of the occurrence of ADRs did not differ. Further, 
Table 4 Incidence of adverse drug reactions of special interest

\begin{tabular}{|c|c|c|}
\hline Special interest & $\mathrm{ADR}(\mathrm{PT})$ & Incidence $(n=4329)$ \\
\hline \multirow[t]{4}{*}{ Gouty arthritis ${ }^{\mathrm{a}}$} & Total & $34(0.79)$ \\
\hline & Gouty arthritis & $34(0.79)$ \\
\hline & Gouty tophus & $1(0.02)$ \\
\hline & Gout & $0(-)$ \\
\hline \multirow[t]{17}{*}{ Hepatic dysfunction $^{\mathrm{b}}$} & Total & $75(1.73 \%)$ \\
\hline & Chronic hepatitis & $1(0.02)$ \\
\hline & Hepatic cirrhosis & $1(0.02)$ \\
\hline & $\begin{array}{l}\text { Hepatic function } \\
\text { abnormal }\end{array}$ & $39(0.90)$ \\
\hline & Hepatic steatosis & $2(0.05)$ \\
\hline & Hyperbilirubinemia & $1(0.02)$ \\
\hline & Liver disorder & $12(0.28)$ \\
\hline & ALT abnormal & $1(0.02)$ \\
\hline & ALT increased & $7(0.16)$ \\
\hline & AST abnormal & $1(0.02)$ \\
\hline & AST increased & $4(0.09)$ \\
\hline & $\begin{array}{l}\text { Blood bilirubin } \\
\text { increased }\end{array}$ & $1(0.02)$ \\
\hline & GGTP abnormal & $1(0.02)$ \\
\hline & GGTP increase & $5(0.12)$ \\
\hline & $\begin{array}{l}\text { Transaminases } \\
\text { increased }\end{array}$ & $1(0.02)$ \\
\hline & Blood ALP increased & $3(0.07)$ \\
\hline & $\begin{array}{l}\text { Hepatic enzyme } \\
\text { increased }\end{array}$ & $1(0.02)$ \\
\hline \multirow[t]{12}{*}{ Skin disorders ${ }^{\mathrm{c}}$} & Total & $41(0.95 \%)$ \\
\hline & Alopecia & $1(0.02)$ \\
\hline & Drug eruption & $7(0.16)$ \\
\hline & Eczema & $2(0.05)$ \\
\hline & Erythema & $2(0.05)$ \\
\hline & Pruritus & $15(0.35)$ \\
\hline & Rash & $8(0.18)$ \\
\hline & Rash generalized & $2(0.05)$ \\
\hline & Rash pruritic & $1(0.02)$ \\
\hline & Urticaria & $2(0.05)$ \\
\hline & Pruritus generalized & $1(0.02)$ \\
\hline & Toxic skin eruption & $2(0.05)$ \\
\hline
\end{tabular}

Values are expressed as $n(\%)$

MedDRA/J version (22.0)

$A D R$ adverse drug reaction, $A L T$ alanine transaminase, $A S T$ aspartate transaminase, ALP alkaline phosphatase, GGTP gamma-glutamyl transpeptidase, MedDRA Medical dictionary for regulatory activities, $P T$ preferred term, $S M Q$ standardized MedDRA queries, SOC symptoms of the organ classification

${ }^{a}$ Extract the following as side effects of gouty arthritis, PT: gouty arthritis, gouty tophus, gout

${ }^{b}$ Extract the following as side effects of hepatic dysfunction, PT that fall under "hepato-biliary disorders of the Organ Classification (SOC)" and "SMQ liver-related laboratory tests, signs and Symptoms of the Organ Classification (SOC)"

${ }^{c}$ Extract the following as side effects of skin disorders, PT classified into skin and subcutaneous tissue disorders in the SOC
Table 5 Incidence of AEs/ADRs of other analysis items

\begin{tabular}{|c|c|c|}
\hline Item & PT & Incidence $(n=4329)$ \\
\hline \multirow[t]{17}{*}{$\mathrm{CV}$ events ${ }^{\mathrm{a}}$} & Total & $34(0.79 \%)$ \\
\hline & Brain stem infarction & $1(0.02)$ \\
\hline & Cerebral artery embolism & $1(0.02)$ \\
\hline & Cerebral hemorrhage & $3(0.07)$ \\
\hline & Cerebral infarction & $11(0.25)$ \\
\hline & Embolic stroke & $1(0.02)$ \\
\hline & Subarachnoid hemorrhage & $1(0.02)$ \\
\hline & Vertebral artery stenosis & $1(0.02)$ \\
\hline & $\begin{array}{l}\text { Thrombotic cerebral infarc- } \\
\text { tion }\end{array}$ & $1(0.02)$ \\
\hline & Acute myocardial infarction & $3(0.07)$ \\
\hline & Angina pectoris & $1(0.02)$ \\
\hline & $\begin{array}{l}\text { Arteriosclerosis coronary } \\
\text { artery }\end{array}$ & $1(0.02)$ \\
\hline & Coronary artery disease & $1(0.02)$ \\
\hline & Myocardial ischemia & $1(0.02)$ \\
\hline & Acute coronary syndrome & $2(0.05)$ \\
\hline & Subdural hematoma & $5(0.12)$ \\
\hline & Subdural hemorrhage & $1(0.02)$ \\
\hline \multirow{4}{*}{$\begin{array}{l}\text { Renal and } \\
\text { urinary tract } \\
\text { disorders }{ }^{b}\end{array}$} & Total & $7(0.16 \%)$ \\
\hline & Calculus urinary & $1(0.02)$ \\
\hline & Cystitis hemorrhagic & $1(0.02)$ \\
\hline & Blood urine present & $5(0.12)$ \\
\hline
\end{tabular}

Values are expressed as $\mathrm{n}(\%)$

MedDRA/J version (22.0)

$A D R$ adverse drug reaction, $A E$ adverse reaction (include events for which a causal relationship has been denied), $C V$ cardiovascular, $P T$ preferred term

${ }^{\mathrm{a}}$ Extract the following as AEs of cardiovascular events

Severe basic terms (PT) classified as SMQ "Ischemic heart disease" and "CNS bleeding and cerebrovascular disease"

${ }^{b}$ Extract the following as ADRs of renal and urinary tract disorders

Preferred terms: ureterolithiasis, calculus urinary, cystitis hemorrhagic, hematuria, nephrolithiasis, blood urine present, red blood cells urine positive

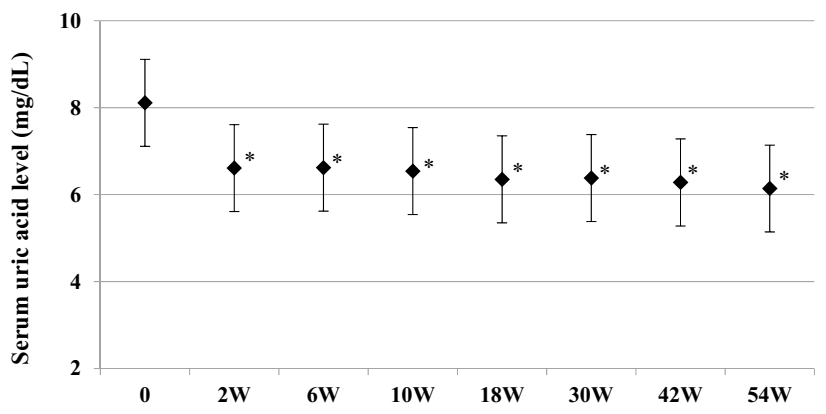

Fig. 2 Changes in serum uric acid levels over time. Values are expressed as mean \pm SD. ${ }^{*} p<0.0001$ (one-sample $t$ test). $S D$ standard deviation 
Table 6 Percentage decrease in serum uric acid level from baseline at each time point

\begin{tabular}{lllllll}
\hline Time point & \multicolumn{2}{l}{ Reduction rate of serum uric acid level $[\%]^{\mathrm{a}}$} & & \multirow{2}{*}{ One-sample $t$ test } \\
\cline { 2 - 6 } & $n$ & Mean \pm SD & Minimum & Median & Maximum & \\
\hline 18 weeks & 2639 & $19.03 \pm 23.90$ & -185.71 & 22.73 & 73.08 & $p<0.0001$ \\
54 weeks & 2191 & $21.19 \pm 22.07$ & -167.50 & 23.75 & 81.08 & $p<0.0001$ \\
Final visit & 3706 & $19.91 \pm 23.35$ & -185.71 & 22.75 & 81.08 & $p<0.0001$ \\
\hline
\end{tabular}

$S D$ standard deviation

${ }^{a}$ Cases with test values at the start of administration and at each time after administration were included

${ }^{b}$ Regardless of the timing, the laboratory values at the time of the final measurement of each case were used

the rate of ADRs is not remarkably high compared with the overall incidence of ADRs at 6.95\% (301/4329 cases).

The incidence of cardiovascular AEs was $0.79 \%$, and of renal and urinary tract disorders was $0.16 \%$, indicating no particular effect on safety.

Regarding efficacy, the reduction rate of serum uric acid level at the end of treatment in clinical trials (long-term administration study at 58 weeks) was $38.44 \% \pm 13.34 \%$ (121 patients), and the achievement rate of $\leq 6.0 \mathrm{mg} / \mathrm{dL}$ was $70.0 \%$ (77/110 subjects) after 18 weeks, and 71.9\% (87/121 subjects) at the end of administration; results of this study were all lower. In clinical trials, all cases were escalated to a maintenance dose of 120 or $160 \mathrm{mg} / \mathrm{day}$, but the average daily dose in this study under actual conditions of use was $<60 \mathrm{mg} /$ day: $71.93 \%$ (3114/4329 cases), which was thought to be because the low-dose cases accounted for the majority, and the escalating cases were as low as $18.34 \%$ (794/4329 cases). Based on these results, it is considered desirable to continue increasing the dose of topiroxostat in the necessary cases.

Table 7 Percentage of patients reaching the serum uric acid level of $6.0 \mathrm{mg} / \mathrm{dL}$ or lower at each time point

\begin{tabular}{|c|c|c|c|c|}
\hline \multirow[t]{2}{*}{ Time point } & \multicolumn{2}{|l|}{ Over all $^{\mathrm{a}}$} & \multicolumn{2}{|c|}{$\begin{array}{l}\text { Serum uric acid level at } \\
\text { the start of administra- } \\
\text { tion exceeds } 6.0 \mathrm{mg} / \mathrm{dL}\end{array}$} \\
\hline & $n$ & $\begin{array}{l}\text { Achieving } \\
\text { rate }(\%)\end{array}$ & $n$ & $\begin{array}{l}\text { Achiev- } \\
\text { ing rate } \\
(\%)\end{array}$ \\
\hline 18 weeks & $1202 / 2744$ & 43.80 & $1004 / 2398$ & 41.87 \\
\hline 54 weeks & $1098 / 2274$ & 48.28 & $914 / 1985$ & 46.05 \\
\hline Final visit ${ }^{\mathrm{c}}$ & $1753 / 3935$ & 44.55 & $1434 / 3383$ & 42.39 \\
\hline
\end{tabular}

${ }^{a}$ Cases with test values at each time after administration were included

${ }^{\mathrm{b}}$ Cases with test values at the start of administration and at each time after administration were included

${ }^{c}$ Regardless of the timing, the laboratory values at the time of the final measurement of each case were used
In addition, we examined the rate of decrease in serum uric acid levels in elderly and female patients, and in patients with hepatic or renal dysfunction, where the number of cases in previous clinical trials has been too small to perform subgroup analyses. Concerning elderly patients and hepatic or renal dysfunction patients, there was no significant difference in the rate of decreases in serum uric acid levels compared to the general study population. Female patients had a higher decrease in serum uric acid levels than males.

In this study, the rate of achievement of serum uric acid level of $6.0 \mathrm{mg} / \mathrm{dL}$ or less and the decrease rate of serum uric acid level, was lower than in reported clinical trials. However, a significant decrease in serum uric acid level was observed, compared to the start of treatment, and approximately half of the patients had a serum uric acid level of $\leq 6.0 \mathrm{mg} / \mathrm{dL}$ at 54 weeks after administration. A decrease in serum uric acid levels was also observed in specific patient populations, demonstrating the efficacy of topiroxostat under actual conditions of use.

Since the urate transporter is greatly involved in the regulation of serum uric acid level, it is also interesting to observe whether XOR inhibitors affect the function of urate transporters, such as URAT1, GLUT9 and ABCG2. ABCG2 variants have been shown to have stronger effects on the risk of hyperuricemia/gout than major environmental risk factors such as obesity and heavy drinking [4]. The most common dysfunction variant rs2231142 (p.Q141K), and the prevalent variant in Japan rs72552713 (p.Q126X), as well as rare variants, increase the risk of gout and hyperuricemia, significantly influence the age of onset of gout, and are highly associated with a familial gout history. The ABCG2 dysfunction was reported as a strong independent risk for pediatric-onset hyperuricemia/gout [19]. Moreover, a significant association between rs2231142 and an increased risk of a poor response to allopurinol has been described [20]. It might be very beneficial to include these common dysfunctional ABCG2 variants in any future study about topiroxostat treatment. 
Table 8 Percentile reduction in serum uric acid levels in a special patient population

\begin{tabular}{|c|c|c|c|c|c|c|c|}
\hline \multirow[t]{3}{*}{ Background } & \multirow[t]{3}{*}{ Category } & \multicolumn{6}{|c|}{ Time after administration } \\
\hline & & \multicolumn{3}{|c|}{18 weeks } & \multicolumn{3}{|c|}{54 weeks } \\
\hline & & $n$ & $\begin{array}{l}\text { Percentile } \\
\text { reduction } \\
(\text { mean \% })^{\mathrm{a}}\end{array}$ & Analysis of variance & $n$ & $\begin{array}{l}\text { Percentile } \\
\text { reduction } \\
(\text { mean \%) }\end{array}$ & Analysis of variance \\
\hline \multicolumn{2}{|l|}{ Total } & 2639 & 19.03 & - & 2191 & 21.19 & - \\
\hline \multirow[t]{3}{*}{ Age (years) } & $<65$ & 1151 & 18.33 & $p=0.0007$ & 934 & 21.01 & $p=0.3343$ \\
\hline & 65 to $<75$ & 711 & 17.25 & & 603 & 20.40 & \\
\hline & $\geq 75$ & 777 & 21.68 & & 654 & 22.19 & \\
\hline \multirow[t]{2}{*}{ Gender } & Male & 2090 & 17.87 & $p<0.0001$ & 1747 & 20.31 & $p p=0.0002$ \\
\hline & Female & 549 & 23.45 & & 444 & 24.67 & \\
\hline \multirow{5}{*}{$\begin{array}{l}\text { Hepatic dysfunc- } \\
\text { tion (Baseline } \\
\text { AST, ALT } \\
[\mathrm{U} / \mathrm{L}])^{\mathrm{b}} \\
\text { Severity }\end{array}$} & No $($ AST $<50$ and ALT < 50) & 2065 & 19.32 & $p=0.8914$ & 1740 & 21.24 & $p=0.9014$ \\
\hline & $\begin{array}{l}\text { Mild (AST } 50 \text { to }<100 \text { or ALT } 50 \\
\text { to }<100 \text { ) }\end{array}$ & 222 & 18.67 & & 175 & 21.70 & \\
\hline & $\begin{array}{l}\text { Moderate (AST } 100 \text { to }<500 \text { or ALT } \\
100 \text { to }<500 \text { ) }\end{array}$ & 45 & 17.97 & & 30 & 19.74 & \\
\hline & Severe $(\mathrm{AST} \geq 500$ or $\mathrm{ALT} \geq 500)$ & 1 & 32.95 & & 0 & - & \\
\hline & Unknown & 306 & 17.42 & & 246 & 20.70 & \\
\hline \multirow{6}{*}{$\begin{array}{l}\text { Renal dysfunc- } \\
\text { tion (baseline } \\
\text { eGFR }[\mathrm{mL} / \\
\left.\left.\text { min } / 1.73 \mathrm{~m}^{2}\right]\right)^{\mathrm{b}} \\
\text { Severity }\end{array}$} & No $(\geq 90)$ & 149 & 19.46 & $p=0.1460$ & 123 & 20.64 & $p=0.5141$ \\
\hline & Mild $(60$ to $<90)$ & 871 & 19.59 & & 730 & 21.00 & \\
\hline & Moderate $(30$ to $<60)$ & 1030 & 19.57 & & 866 & 21.83 & \\
\hline & Severe $(15$ to $<30)$ & 254 & 16.15 & & 210 & 18.80 & \\
\hline & End stage renal failure $(<15)$ & 153 & 16.27 & & 109 & 21.54 & \\
\hline & Unknown & 182 & 19.22 & & 153 & 21.99 & \\
\hline
\end{tabular}

$A L T$ alanine transaminase, $A S T$ aspartate transaminase, $e G F R$ estimated glomerular filtration rate

${ }^{a}$ The subjects were those whose laboratory values were at the start of administration and at each time after administration

${ }^{\mathrm{b}}$ Judgment based only on baseline clinical test values

\section{Conclusions}

As a result of the study under actual conditions of use, there were no new findings that would raise questions about the safety of topiroxostat, and the efficacy of this drug was shown to be the same as had been reported in clinical studies at the time of approval. Therefore, topiroxostat is considered to be a safe and effective drug for gout and hyperuricemia in daily practice.

Acknowledgements The authors thank all physicians from the 825 institutions and the physicians who participated in this study, for their cooperation. This study was funded by Fuji Yakuhin Co., Ltd. and Sanwa Kagaku Kenkyusho Co., Ltd.

\section{Compliance with Ethical Standards}

Conflict of interest YK is a medical advisor of Fuji Yakuhin Co., Ltd., and received consultant fees. TI, TH and YS are employees of Fuji Yakuhin Co., Ltd., TM, TN and KI are employees of Sanwa Kagaku Kenkyusho Co., Ltd.
Ethics approval This study was carried out in accordance with the good post-marketing study practice standards specified by the Ministry of Health, Labor and Welfare in Japan. According to good post-marketing study practice in Japan, ethics approval was not required for this postmarketing study.

Informed consent According to good post-marketing study practice in Japan, informed consent was not required for this post-marketing study. As such, informed consent was not obtained from the individual participants included in the study.

Open Access This article is licensed under a Creative Commons Attribution-NonCommercial 4.0 International License, which permits any non-commercial use, sharing, adaptation, distribution and reproduction in any medium or format, as long as you give appropriate credit to the original author(s) and the source, provide a link to the Creative Commons licence, and indicate if changes were made. The images or other third party material in this article are included in the article's Creative Commons licence, unless indicated otherwise in a credit line to the material. If material is not included in the article's Creative Commons licence and your intended use is not permitted by statutory regulation or exceeds the permitted use, you will need to obtain permission directly from the copyright holder. To view a copy of this licence, visit http://creativecommons.org/licenses/by-nc/4.0/. 


\section{References}

1. Yamanaka H, Japanese Society of Gout and Nucleic Acid Metabolism. Japanese guideline for the management of hyperuricemia and gout: second edition. Nucl Nucl Nucleic Acids. 2011;30:1018-29.

2. Ichida K, Matsuo H, Takada T, Nakayama A, Murakami K, Shimizu T, et al. Decreased extra-renal urate excretion is a common cause of hyperuricemia. Nat Commun. 2012;3:764.

3. Matsuo H, Tsunoda T, Ooyama K, Sakiyama M, Sogo T, Takada $\mathrm{T}$, et al. Hyperuricemia in acute gastroenteritis is caused by decreased urate excretion via ABCG2. Sci Rep. 2016;6:31003.

4. Nakayama A, Matsuo H, Nakaoka H, Nakamura T, Nakashima $\mathrm{H}$, Takada Y, et al. Common dysfunctional variants of ABCG2 have stronger impact on hyperuricemia progression than typical environmental risk factors. Sci Rep. 2014;4:5227.

5. Khanna D, Fitzgerald J, Khanna P, Bae S, Singh M, Neogi T, et al. 2012 American College of Rheumatology guidelines for management of gout. Part 1: systematic nonpharmacologic and pharmacologic therapeutic approaches to hyperuricemia. Arthritis Care Res. 2012;64:1431-46.

6. Richette P, Doherty M, Pascual E, Barskova V, Becce F, Castañeda-Sanabria J, et al. 2016 updated EULAR evidence-based recommendations for the management of gout. Ann Rheum Dis. 2017;76:29-42.

7. Sivera F, Andrés M, Carmona L, Kydd A, Moi J, Seth R, et al. Multinational evidence-based recommendations for the diagnosis and management of gout: integrating systematic literature review and expert opinion of a broad panel of rheumatologists in the $3 \mathrm{e}$ initiative. Ann Rheum Dis. 2014;73:328-35.

8. Sattui SE, Gaffo AL. Treatment of hyperuricemia in gout: current therapeutic options, latest developments and clinical implications. Ther Adv Musculoskelet Dis. 2016;8:145-59.

9. Okamoto K, Matsumoto K, Hille R, Eger BT, Pai EF, Nishino T. The crystal structure of xanthine oxidoreductase during catalysis: implications for reaction mechanism and enzyme inhibition. Proc Natl Acad Sci USA. 2004;101:7931-6.

10. Matsumoto K, Okamoto K, Ashizawa N, Nishino T. FYX-051: a novel and potent hybrid-type inhibitor of xanthine oxidoreductase. J Pharmacol Exp Ther. 2011;336:95-103.

11. Hosoya T, Sasaki T, Hashimoto H, Sakamoto R, Ohashi T. Clinical efficacy and safety of topiroxostat in Japanese male hyperuricemic patients with or without gout: an exploratory, phase 2a, multicentre, randomized, double-blind, placebo-controlled study. J Clin Pharm Ther. 2016;41:298-305.

12. Hosoya T, Sasaki T, Ohashi T. Clinical efficacy and safety of topiroxostat in Japanese hyperuricemic patients with or without gout: a randomized, double-blinded, controlled phase $2 \mathrm{~b}$ study. Clin Rheumatol. 2017;36:649-56.

13. Hosoya T, Ogawa Y, Hashimoto H, Ohashi T, Sakamoto R. Comparison of topiroxostat and allopurinol in Japanese hyperuricemic patients with or without gout: a phase 3 , multicentre, randomized, double-blind, double-dummy, active-controlled, parallel-group study. J Clin Pharm Ther. 2016;41:290-7.

14. Hosoya T, Ohno I, Nomura S, Hisatome I, Uchida S, Fujimori S, et al. Effects of topiroxostat on the serum urate levels and urinary albumin excretion in hyperuricemic stage 3 chronic kidney disease patients with or without gout. Clin Exp Nephrol. 2014;18:876-84.

15. Hosoya T, Ishikawa T, Ogawa Y, Sakamoto R, Ohashi T. Multicenter, open-label study of long-term topiroxostat (FYX-051) administration in Japanese hyperuricemic patients with or without gout. Clin Drug Investig. 2018;38:1135-43.

16. Mizukoshi T, Kato S, Ando M, Sobajima H, Ohashi N, Naruse $\mathrm{T}$, et al. Renoprotective effects of topiroxostat for hyperuremic patients with overt diabetic nephropathy study (ETUDE Study): a prospective, randomized, multicenter clinical trial. Nephrology. 2018;23:1023-30.

17. Wada T, Hosoya T, Honda D, Sakamoto R, Narita K, Sasaki T, et al. Uric acid-lowering and renoprotective effects of topiroxostat, a selective xanthine oxidoreductase inhibitor, in patients with diabetic nephropathy and hyperuricemia: a randomized, doubleblind, placebo-controlled, parallel-group study (UPWARD study). Clin Exp Nephrol. 2018;22:860-70.

18. Hakoda M, Kasagi F. Increasing trend of asymptomatic hyperuricemia under treatment with urate-lowering drugs in Japan. Mod Rheumatol. 2019;29:880-4.

19. Stiburkova B, Pavelcova K, Pavlikova M, Ješina P, Pavelka K. The impact of dysfunctional variants of ABCG2 on hyperuricemia and gout in pediatric-onset patients. Arthritis Res Ther. 2019;21:77.

20. Roberts RL, Wallace MC, Phipps-Green AJ, Topless R, Drake JM, Tan $\mathrm{P}$, et al. ABCG2 loss-of-function polymorphism predicts poor response to allopurinol in patients with gout. Pharmacogenom J. 2016;17:201-3. 